Article

\title{
Geostructural and Geomechanical Study of the Piastrone Quarry (Seravezza, Italy) Supported by Photogrammetry to Assess Failure Mode
}

\author{
Sabrina Bonetto $\left.{ }^{1} \mathbb{(}\right)$, Gessica Umili ${ }^{1} * \mathbb{1}$, Anna Maria Ferrero ${ }^{1}$, Rodolfo Carosi ${ }^{1}$, \\ Matteo Simonetti ${ }^{1}$ (D), Alessandro Biasi ${ }^{1}$, Maria Rita Migliazza ${ }^{2}$ and Stefano Bianchini ${ }^{3}$ \\ 1 Department of Earth Sciences, Università degli Studi di Torino, via Valperga Caluso 35, 10125 Torino, Italy; \\ sabrina.bonetto@unito.it (S.B.); anna.ferrero@unito.it (A.M.F.); rodolfo.carosi@unito.it (R.C.); \\ matteo.simonetti@unito.it (M.S.); alessandro.biasi@edu.unito.it (A.B.) \\ 2 Department of Structural, Geotechnical and Building Engineering, Politecnico di Torino, \\ Corso Duca degli Abruzzi 24, 10129 Torino, Italy; maria.migliazza@polito.it \\ 3 Mining Engineer, 54033 Carrara, Italy; s.bianchini@marmotest.com \\ * Correspondence: gessica.umili@unito.it; Tel.: +39-011-6705114
}

Received: 24 December 2019; Accepted: 5 February 2020; Published: 8 February 2020

check for updates

\begin{abstract}
The use of non-contact-techniques for rock mass characterization has been growing significantly over the last decade. However, their application to stability assessment of ornamental stone has not yet received much attention from researchers. This study utilizes rock mass data both in terms of slope orientations and degree of fracturing obtained from a point cloud, a set of three-dimensional (3D) points representing a rock mass surface, to (1) investigate the influence of geostructures at different scales and (2) assess quarry stability by determining areas susceptible to different failure types. Multi-resolution point clouds are obtained through several photogrammetric survey techniques to identify important structural elements of the site. By integrating orientation data of discontinuity planes, obtained with a traditional survey, and of traces, outlined on point clouds, several joint sets were identified. Kinematic tests revealed various potential failure modes of the rock slope. Moreover, an analysis of the influence of the discontinuity strength determined by the presence of rock bridges was carried out. The study revealed that the strength of the quarry face is governed by the presence of rock bridges that act to improve the stability condition of the rock fronts.
\end{abstract}

Keywords: marble quarry; slope stability; geostructural survey; point cloud; photogrammetry

\section{Introduction}

Surveying of geometric characteristics of discontinuities in a rock mass is fundamental for the evaluation of potential detachable blocks. A geostructural survey devoted to a systematic and quantitative description of rock discontinuities is crucial to understand the stability conditions of a rock mass. Discontinuity sampling can be applied to rock faces, natural or artificial (such as excavations), or on boreholes depending on the available data. Discontinuity properties to be measured include dip, dip direction, length, spacing, roughness, persistence, aperture, filling, and termination [1]. A correct joint geometry representation is suggested by ISRM [2], providing that a collected sample is representative of the entire joint population [3,4]. Measurements of dip and dip direction are used to represent the discontinuity orientation on a two-dimensional (2D) map, in order to describe the directional aspects of joints, faults, bedding planes and any other fracture present into the rock mass.

However, in certain contexts, such as ornamental stone quarries, traditional survey method could lead to inaccurate and incomplete results, due to conditions of faces and the excavation environment. In fact, in addition to being a very demanding environment in terms of safety for both workers and 
possible people performing the survey (chain-sawing machines and/or diamond wire saws at work, heavy machineries carrying blocks, etc.), the peculiarity of a quarry is the presence of both natural rock faces and excavated benches. The traditional geomechanical survey allows for both geometric and geomechanical (roughness, alteration, etc.) description of the discontinuities that intersect the scanline; however, it is limited in terms of accessibility of the higher portions of the slope and it can be very time demanding for large rock slopes.

To overcome these limitations, recent advances in non-contact survey techniques are becoming increasingly used; digital photography for mapping traces [5-12] and detecting failure [13-15], digital photogrammetry, or laser scanner for surveying discontinuity planes [16-25].

The acquisition of three-dimensional (3D) data of the terrain surface is now obtained with a high accuracy, in less time and over a wider area thanks to the evolution of satellite and remote sensing imaging technologies. This progress has also changed the way to collect and interpret information about the geostructural setting of large areas [26-30] or the structure of rock mass for the stability assessment [31-37], with the great advantage of allowing for the survey of high inaccessible steep slopes in safe conditions. To become a real alternative (both in terms of productivity as well as accuracy) to a traditional survey, interactive or automated software tools are necessary, to allow the efficient selection on the point cloud of elements of interest (i.e., discontinuity planes and traces, etc.).

In this work, image sequences shot both from remotely piloted aircraft and from the ground have been used to obtain 3D point clouds to be analyzed for extracting information on the discontinuity orientation and persistence at different scales, to be coupled with data from traditional surveys and geostructural studies.

The test site is a marble quarry, called Piastrone, in the Carrara extraction basin: excavation process has brought to light the rock mass, allowing for a complete outcrop of the rock structure and making the place an ideal site for rock mechanics studies.

\section{Failure Mode in Ornamental Stone Quarries}

Ornamental stone exploitation is based on the extraction of large sound rock blocks to be cut into slabs by special frames. Such an operation is possible only in massive rock masses characterized by a low degree of fracturing. This main feature also affects the possible failure modes occurring along the excavation fronts.

Pre-existing discontinuities and their orientation, in relation with the orientation of excavation, determines the possible kinematic instability mode: some case studies regarding different kinds of quarry are reported in [38-41]. Stability conditions are further affected by discontinuity persistence in the form of rock bridges that can increase the available shear resistance [42-44]. Finally, the volume of detachable rock block is determined by spacing of rock joints.

Planar or wedge sliding, flexural or block toppling must be identified before stability analysis are performed [45]. Stereographic projections for the kinematic analysis of these simple failure modes are described by Richards et al. [46] and Hoek and Bray [47].

In massive rock masses, consequently, the assessment of the discontinuity geometrical features is of crucial importance for an accurate evaluation of stability conditions of the potentially unstable volume.

\section{Geological and Structural Setting}

Piastrone quarry is located in the territory of Seravezza (Lucca, Italy). It is part of the northern slope of Mt. Altissimo in the extraction district of the Apuan Alps. The mining activity was recently resumed after about thirty years of inactivity. It is an open pit quarry (Figure 1) and it extends between $1179 \mathrm{~m}$ and $1280 \mathrm{~m}$ a.s.l. The metamorphic complex of the Apuan Alps crops out in the northern Apennines. It consists of a Paleozoic basement and its Meso-Cenozoic metasedimentary cover, metamorphosed up to greenschist facies conditions [48,49]. It is separated from the overlying non-metamorphic sedimentary rocks of the Tuscan nappe and Liguride units by breccias and cataclasites belonging to the "Calcare Cavernoso" formation that acted as a slip horizon both during Oligocene and Miocene [48]. 




Figure 1. View of the Piastrone open pit quarry.

According to Carmignani and Kligfield [48] in the Apuan Alps two deformation phases, D1 and D2, can be recognized. During D1, which is linked to the nappe staking, kilometric-scale folds with an associated axial plane foliation (S1), and a stretching lineation (L1) were developed. Carmignani and Kligfield [48] and Molli [50] recognized during D1 a northeast transport direction by considering the map-scale and meso-scale geometry of folds.

The peak metamorphism, estimated at 350-450 ${ }^{\circ} \mathrm{C}$ and $0.6 \mathrm{GPa}$ [49], was reached during the early D1 phase and was dated at $27 \mathrm{Ma}\left(\mathrm{K}-\mathrm{Ar}\right.$ and ${ }^{40} \mathrm{Ar}-{ }^{39} \mathrm{Ar}$ on white mica [51]). The D2 event is responsible of the formation of a complex mega-antiform with Apenninic trending axis (NW-SE) during the exhumation of the metamorphic units [48,52]. D2 is correlated to the development of folds with an associated S2 foliation and high-strain shear zones. D2 phase initiated at temperature higher than $250{ }^{\circ} \mathrm{C}$ and is considered to happen earlier than $11 \mathrm{Ma}$ according to zircon fission track ages [53].

The final exhumation and uplift of the metamorphic units is characterized by the transition from a ductile to a brittle regime, with the formation of kink folds, low- and high-angle faults, and joint systems [48].

The Piastrone quarry exploits marbles cropping out in the normal limb of a km-scale fold. The fold is a syncline, with younger rocks in its core and older rocks in the limbs, and it is named as "Monte Altissimo syncline" [54] (Figure 2). The fold has a marble core and the axis trends NW-SE with axial plane schistosity dipping to SW. This fold developed during the oligo-miocenic tectonics linked to the D1 deformation event in the Apuan Alps and the Northern Apennines.

All the formations that outcrop in the quarry area belong to the Apuane Unit (Autoctono "Auct.") that underwent metamorphism in low temperature and pressure conditions (greenschist metamorphism) during the thickening stage of the Northern Apennines. The following lithologies are present from the older to the younger [56]: (a) white marble (Figure 3a) of Raethian age known in literature as Megalodon-bearing marble; (b) metabreccia of Raethian-Liassic age made by marble and dolomitic clasts (Figure 3b) within a red or green chloritoid-bearing phylladic matrix known as Seravezza breccia; (c) massive white marble interbedded with grey marble strata (Figure 3c), characterized by veins and brecciated levels, of Hettangian age [54]. The last two lithologies belongs to 
the "Marmi stricto sensu (s.s.) Formation", which is the main formation that crops out in the study area and the target of the mining activity.

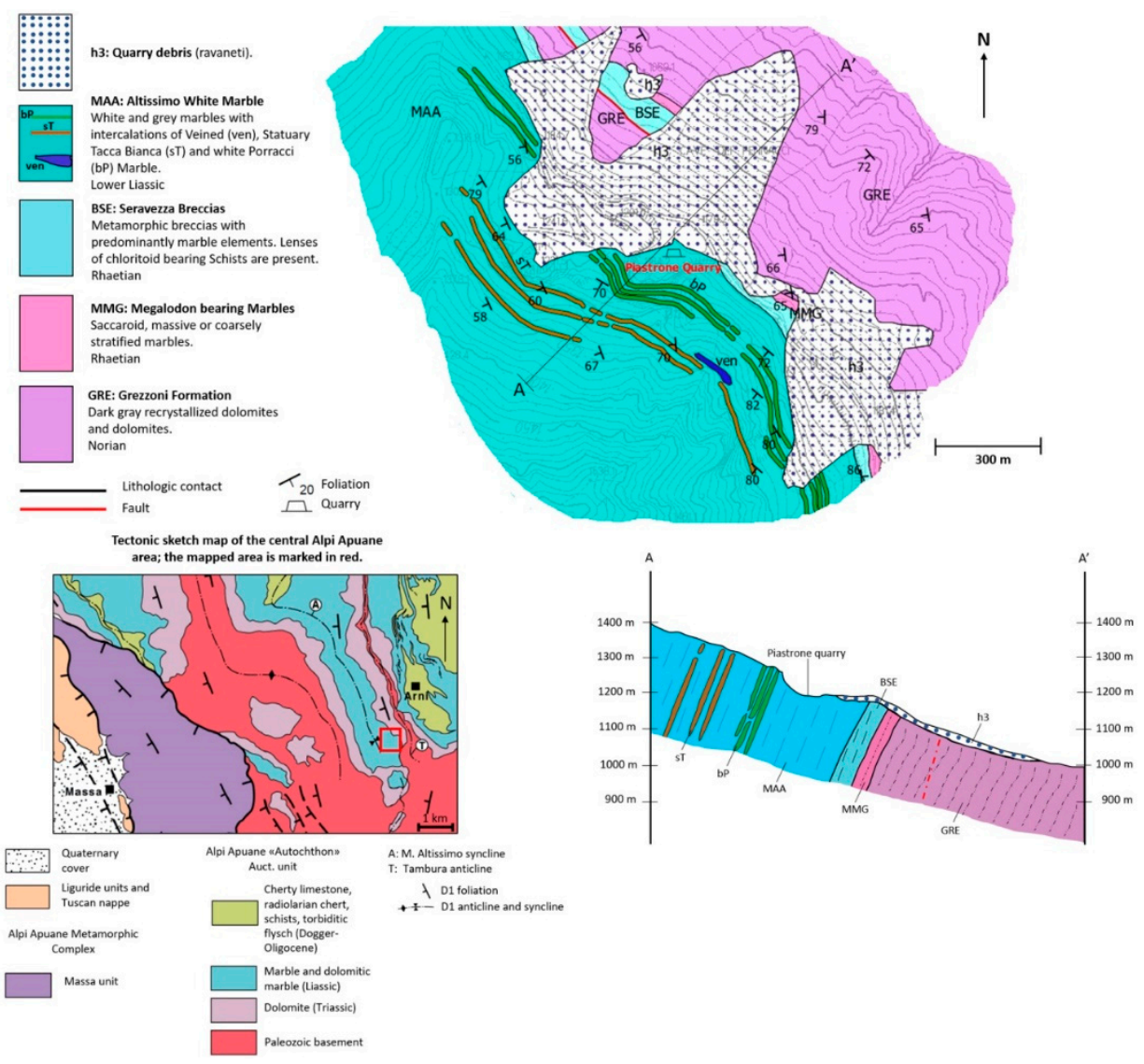

Figure 2. Geological map of the "Retro Altissimo" extraction district [55]; location of Piastrone quarry is marked in red.
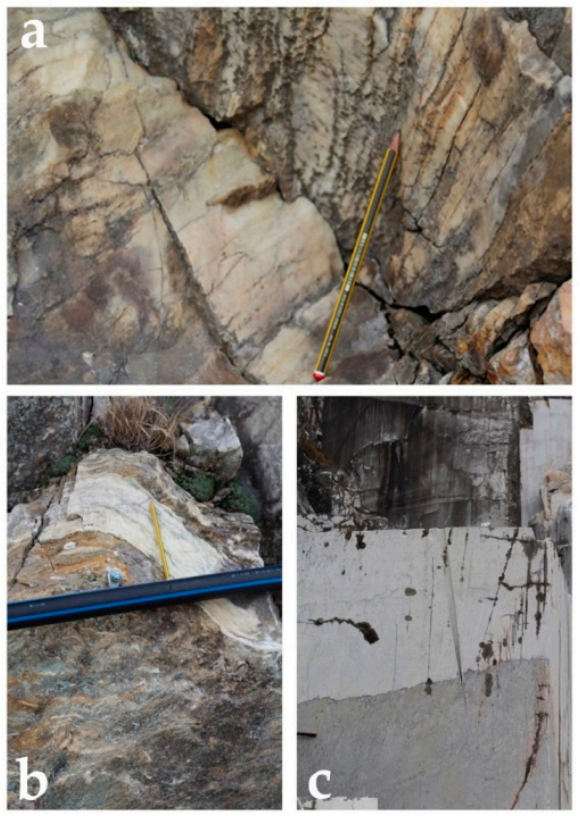

Figure 3. Outcrop appearance of the lithologies of the study area: (a) Megalodon-bearing marble, (b) Seravezza breccia, (c) contact between white and grey marbles. 
In the study area, D1 structures are present in the marble (Figure 4): here, the sedimentary bedding (S0) is folded and crosscut at medium-high angle by a penetrative S1 foliation, oriented NW-SE and dipping at high-angle toward SW (Figure 5). On this foliation, a L1 mineral lineation plunges at medium angle toward W-SW. These data are in good agreement with results obtained by Molli et al. [57] in the Apuane Unit (Figure 5).

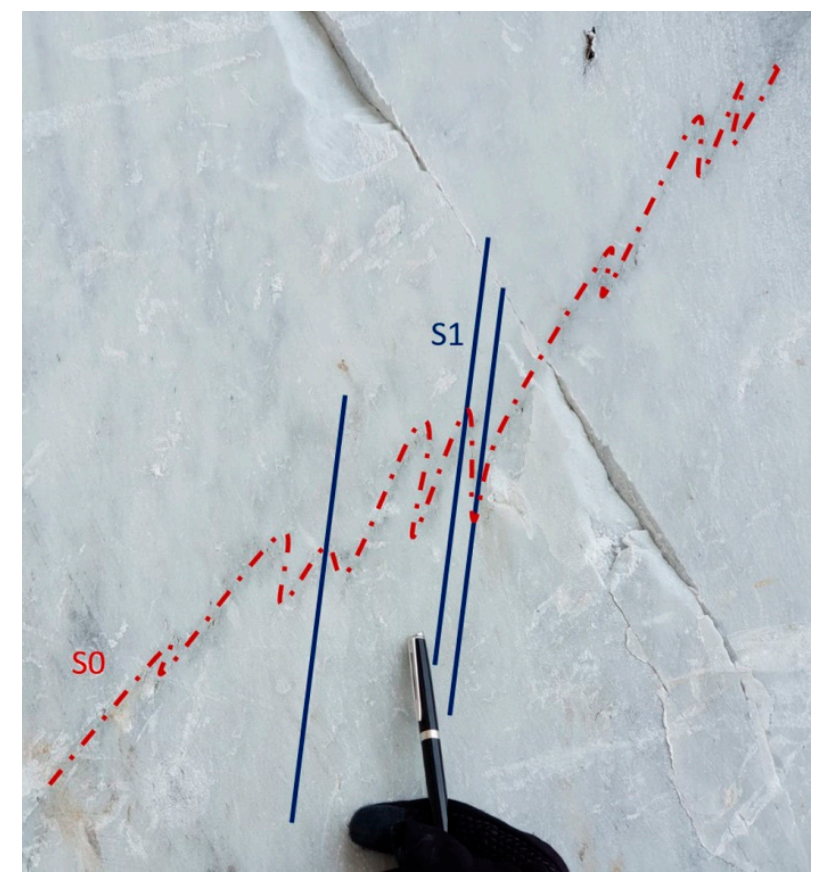

Figure 4. Outcrop-scale evidence of deformed of bedding (S0) and foliation (S1) in the "marmi s.s." (marble).

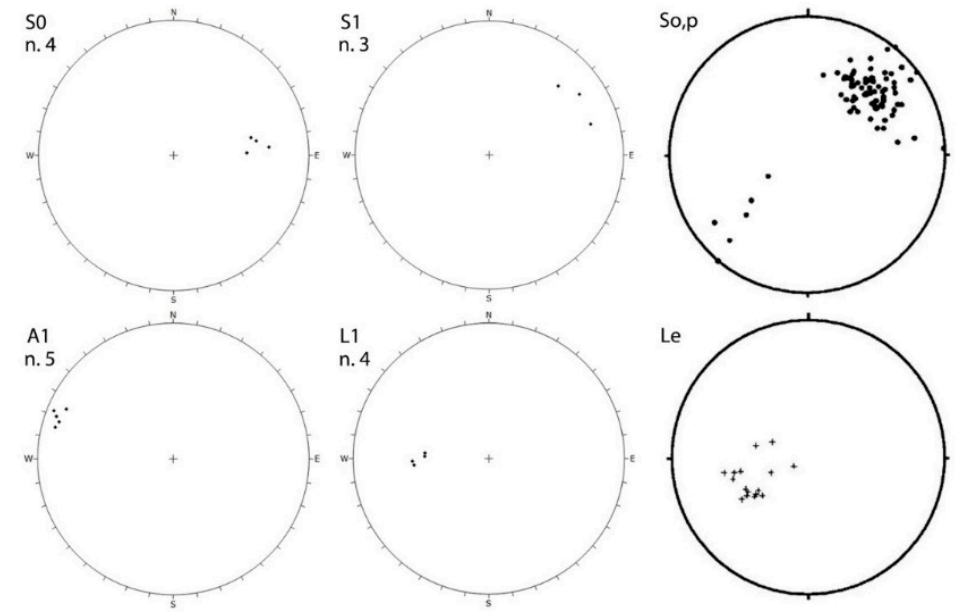

Figure 5. Equal area, lower hemisphere projections of D1 structural elements measured in the study area: S0 sedimentary bedding, S1 foliation, L1 stretching lineation, A1 fold axis. On the right: bedding parallel D1 foliation (p), extension and mineral lineation (Le) (modified from [57]).

Early D2 deformation structures are not present in the study area. Late D2 deformation is associated with the development of a network of joints, fractures and faults (Figure 6) under brittle conditions. Faults show mainly a strike-slip kinematic and, in places, also a minor normal component. 

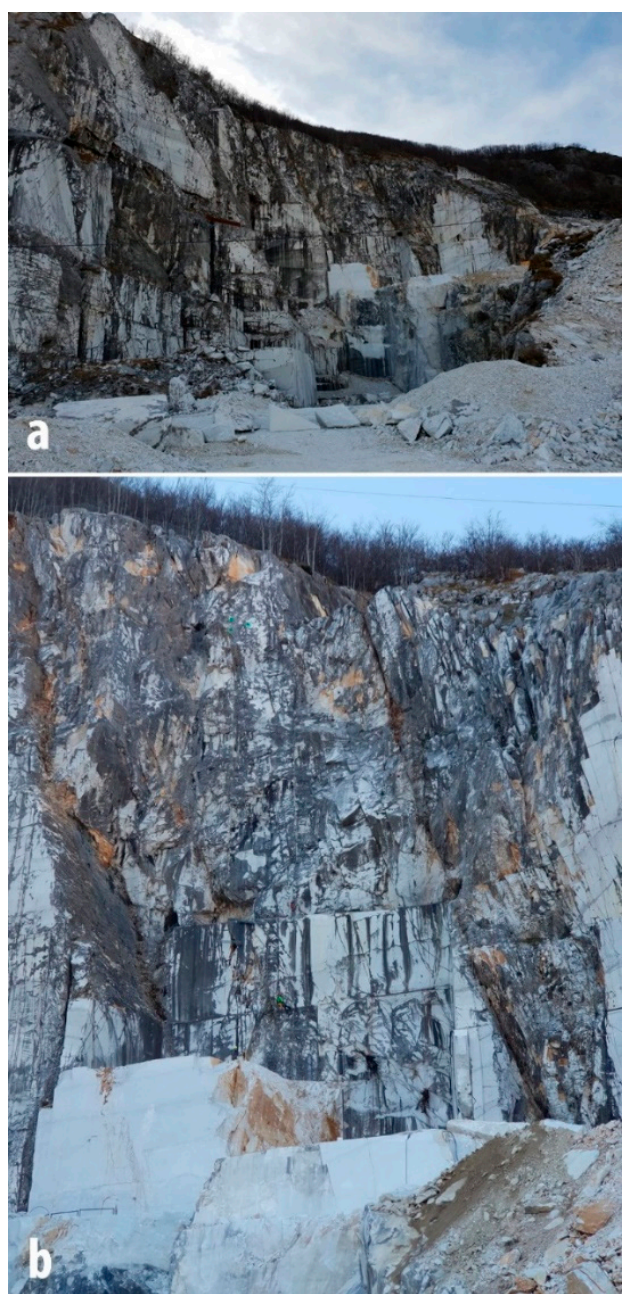

Figure 6. (a) strike-slip faults cross-cutting the Marmi s.s. Formation in the quarry area; (b) detail of the fault and damage zone.

Microstructural analysis of the studied marbles highlights a granoblastic and isotropic structure. In some cases, crystals present straight grain boundaries while in other cases the grain boundary is lobed (Figure 7). Those features are indicative of a late- or post-D1 static recrystallization.

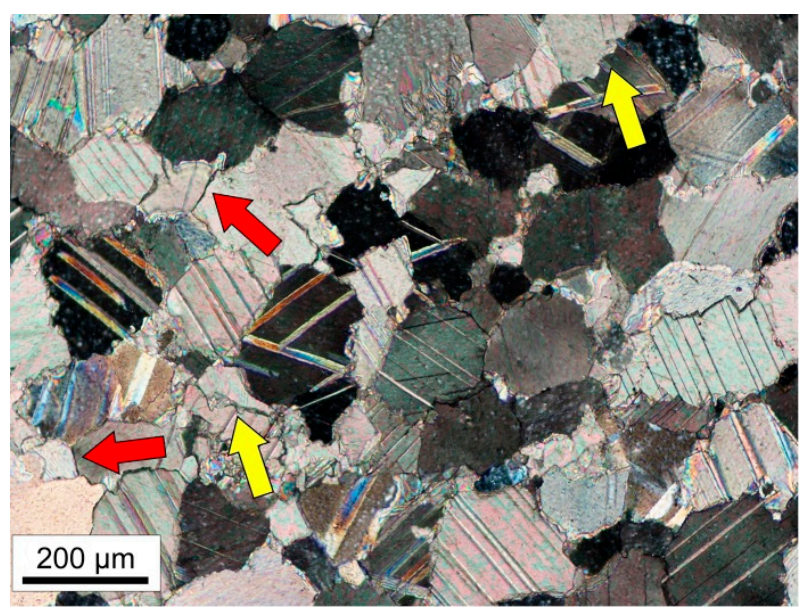

Figure 7. Typical granoblastic structure of the marble of Piastrone quarry: both straight (red arrows) and lobated (yellow arrows) grain boundaries can be recognized in calcite crystals. 


\section{Materials and Methods}

\subsection{Geomechanical Survey}

For the purposes of cataloguing and characterization of the discontinuity sets, a geomechanical survey campaign was performed according to ISRM standards [2], describing all the discontinuities intersecting a scanline. Moreover, bibliographic data by Lorenzoni [58] were utilized for comparison. Seven traditional surveys along horizontal scanlines were performed, of which four were on excavation faces in the upper portion of the quarry, located at about $1260 \mathrm{~m}$ a.s.l. and three in the intermediate part at $1224 \mathrm{~m}$ a.s.l. (Figure 8).

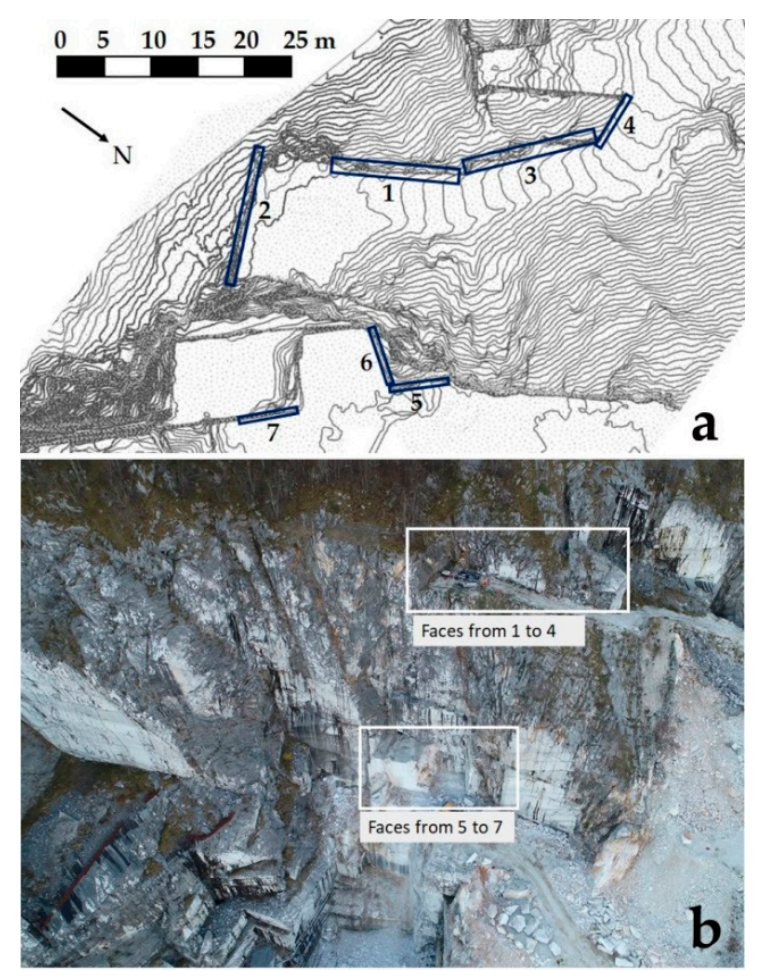

Figure 8. (a) Location of the seven surveys along scanlines performed in the quarry; (b) image of the quarry showing locations of faces from 1 to 7.

\subsection{Non-Contact Survey}

Non-contact techniques are based on the setting up and elaboration of 3D models, each consisting of a dense cloud of points representing the area of study. Many digital image sequences were shot, both from remotely piloted aircraft and from the ground, covering all the quarry area. The technical specifications of the instrumentation are reported in Table 1. Digital image sequences were processed by the photogrammetric software Photoscan [59]: this code is based on Structure from Motion algorithms and is able to reconstruct the surface of the photographed object, by calculating the tridimensional coordinates of the points of the surface, and to assign a colored texture to the surface. Point clouds, namely sets of 3D points representing, in this case, portions of rock mass surface, were created and georeferenced, namely referred to the chosen reference system, by inputting the coordinates of points acquired by GPS.

Specifically, two point clouds were provided: the first one represents the entire quarry (Figure 9a) and was obtained from digital images shot by a camera carried by a drone; dimensions of the point cloud are about $350 \times 250 \times 160 \mathrm{~m}$, with a total of 11,117,143 points and an average resolution of 1 point every $0.1 \mathrm{~m}$. 
Table 1. Technical specifications of the instrumentation used for the photogrammetric survey.

\begin{tabular}{cccc}
\hline \multicolumn{2}{c}{ Aerial Survey } & \multicolumn{2}{c}{ Terrestrial Survey } \\
\hline Remotely piloted aircraft & DJI Phantom 4 Pro & Camera & Nikon D800 \\
Camera resolution & $5520 \times 3680$ & Camera resolution & $7360 \times 4912$ \\
Focal length & $24 \mathrm{~mm}$ & Focal lengths & $24 \mathrm{~mm}, 35 \mathrm{~mm}$ \\
\hline
\end{tabular}

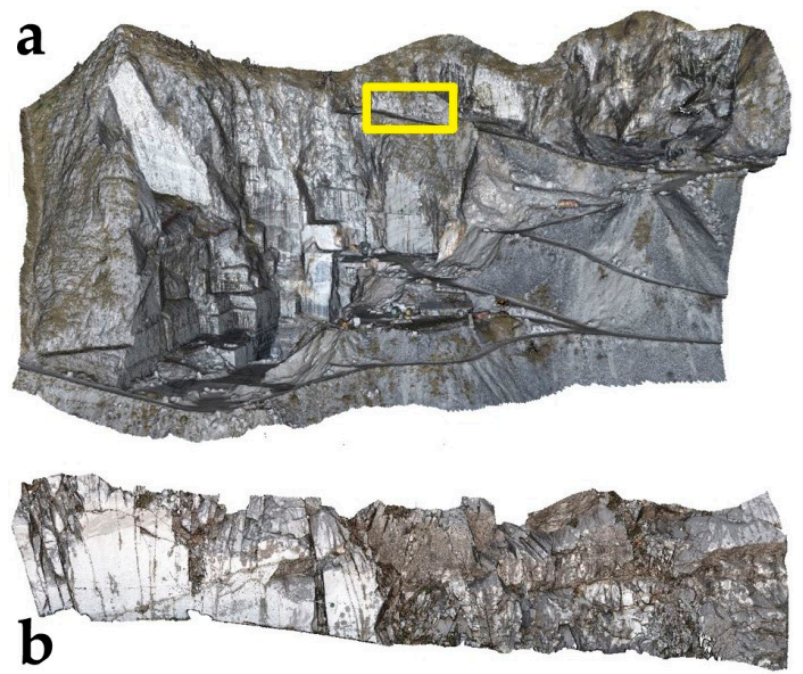

Figure 9. Point cloud representing (a) the entire quarry (in yellow the location of bench in the quarry); (b) the studied bench.

The second point cloud (Figure $9 \mathrm{~b}$ ) represents with a higher degree of detail the studied bench, positioned at about $1260 \mathrm{~m}$ a.s.l., and includes excavation faces 1 and 3 (Figure 8). It was created by means of close-range images shot from the ground; the point cloud in this case is very similar to a plane of about $28 \times 10 \mathrm{~m}$, with a total of 1,439,000 points and an average resolution of 1 point every $0.01 \mathrm{~m}$.

The models were analyzed using CloudCompare [60], in particular with the Trace tool included in qCompass plugin. This tool allows the user to manually draw a segment connecting two points of the point cloud in order to automatically obtain its orientation in terms of trend and plunge. Along the excavation face discontinuity traces, namely intersections between the plane of the face and discontinuity planes, are outlined as segments and their orientations plotted on a stereonet. The procedure was repeated both in the case of the excavation face in detail (separated into two portions representing excavation faces 1 and 3, respectively, characterized by different degrees of fracturing) and the entire quarry.

\subsection{Stability Assessment}

Once the main discontinuity sets are known, it is possible to perform a stability analysis along the different excavation faces. The first step is a kinematic analysis, using the Markland Test [61] as modified by Hudson and Harrison [62] in order to identify along which discontinuities potential kinematic mechanisms may arise. In this case, the test was carried out with respect to planar and three-dimensional (wedge) sliding by means of Dips software [63]. Planar sliding occurs in rock masses where a discontinuity set has an average dip direction similar to the slope face dip direction. Wedge sliding occurs when two discontinuity surfaces intersect on a line, which has a dip direction coming out of the slope face. These geometric relationships, in addition to a dip value of plane (intersection, in case of wedge sliding) greater than friction angle, are the conditions for the verification of the test.

The factor of safety (FoS) was calculated for every joint set (or combination of sets, in case of wedge sliding) resulting in a positive response of the test on the considered fronts. FoS was calculated 
according to the limit equilibrium method (LEM) and is interpreted as the ratio between resisting forces $F_{R}$ that oppose the movement of a block and forces $F_{A}$ acting in favor of the kinematic motion. With respect to planar sliding, FoS was calculated according to three resistance criteria:

1. Mohr-Coulomb criterion with fully (100\%) persistent joint (Figure 10a): in this case, the cohesion is considered null.

2. Mohr-Coulomb criterion with less than $100 \%$ persistent (therefore not fully persistent) joints, due to the presence of rock bridges, namely intact portions of rock that constitute a considerable resistant contribution.

The cohesion of the rock bridges, called apparent cohesion, is ideally spread along the entire discontinuity (Figure 10b). Apparent cohesion capp was assumed as a portion of intact rock cohesion $c_{\text {int }}$, ruled by persistence $P$ as expressed by the formula:

$$
c_{\text {app }}=c_{\text {int }} \cdot(1-P)
$$

Persistence $\mathrm{P}$ was assumed equal to the ratio between trace length measurable on an excavation face and the dimension of the face that is more similar to the direction of the discontinuity; trace length was determined with non-contact survey, in particular measuring, by means of CloudCompare, segments representing traces on point clouds.

3. Barton-Bandis criterion [64], which considers conditions of peak resistance and persistence of joints equal to $100 \%$.
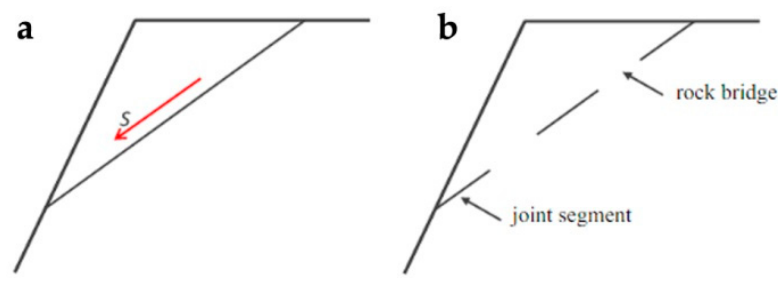

Figure 10. Slope section representing (a) a fully persistent joint (persistence equal to 100\%), (b) an intermittent joint (persistence $<100 \%$ due to rock bridges) (from [65]).

To improve confidence in the results, FoS with respect to planar sliding was calculated in two ways: the analytical method developed on a spreadsheet and RocPlane software [66], theoretically based on the same calculation process. Equations adopted for the analytical model are the following ones [45]:

- Mohr-Coulomb criterion in the absence of cohesion:

$$
\mathrm{FoS}=\frac{F_{R}}{F_{A}}=\frac{\tan \Phi_{r}}{\tan \alpha}
$$

- Mohr-Coulomb criterion with apparent cohesion:

$$
\mathrm{FoS}=\frac{F_{R}}{F_{A}}=\frac{c_{a p p} A+W \cos \alpha \cdot \tan \Phi_{r}}{W \sin \alpha}
$$

- Barton-Bandis criterion:

$$
\mathrm{FoS}=\frac{F_{R}}{F_{A}}=\frac{\tan \Phi_{p}}{\tan \alpha}
$$

FoS equations according to Mohr-Coulomb criterion in absence of cohesion and to Barton-Bandis criterion are geometric relationships given by the ratio between the tangent of residual $\left(\Phi_{\mathrm{r}}\right)$ and peak $\left(\Phi_{\mathrm{p}}\right)$ friction angle, respectively, and the tangent of inclination (dip) of the discontinuity $(\alpha)$, while 
in case of Mohr-Coulomb criterion with presence of cohesion, the area of sliding surface (A) and the weight of sliding block $(\mathrm{W})$ are also involved.

FoS with respect to wedge sliding was calculated considering two different situations: in the first one, persistence of joints is equal to $100 \%$ and cohesion is zero (Equation (5)), while in the second one, persistence is less than $100 \%$ and there are rock bridges producing a certain apparent cohesion (Equation (6)). The following formulas were applied [45]:

$$
\begin{gathered}
\mathrm{FoS}=A \tan \phi_{r A}+B \tan \phi_{r B} \\
\mathrm{FoS}=\frac{3}{\gamma H}\left(c_{a p p A} X+c_{a p p B} Y\right)+A \tan \phi_{r A}+B \tan \phi_{r B}
\end{gathered}
$$

In addition to volume weight of the rock $(\gamma)$ and height of the front $(\mathrm{H})$, apparent cohesion of the two discontinuity planes $\mathrm{A}$ and $\mathrm{B}\left(\mathrm{c}_{\mathrm{appA}}\right.$ and $\left.\mathrm{c}_{\mathrm{appB}}\right)$ and their residual friction angles $\left(\Phi_{\mathrm{rA}}\right.$ and $\left.\Phi_{\mathrm{rB}}\right)$ are of considerable importance; coefficients $\mathrm{A}, \mathrm{B}, \mathrm{X}$, and $\mathrm{Y}$ depend on the geometry of the wedge [45]. To improve confidence in the results, FoS values are calculated using two approaches: the analytical method developed on a spreadsheet and Swedge software [67], theoretically based on the same calculation process.

\section{Results and Discussion}

\subsection{Identification of the Main Discontinuity Sets}

Discontinuities orientation data, obtained with the compass along seven scanlines, each materialized on a different excavation face (Figure 8), were plotted on stereonets by means of Dips software [63]. Five main sets of discontinuities were obtained, and then compared with those described by Lorenzoni [58]. This comparison led to the confirmation of the obtained results: sets are reported in terms of ranges of variability of dip and dip direction (Table 2) and represented in Figure 11.

Table 2. Range of variability of main discontinuity sets.

\begin{tabular}{lcc}
\hline Set & Dip Range $\left[^{\circ}\right]$ & Dip Direction Range $\left[{ }^{\circ}\right]$ \\
\hline K1 & $45-60$ & $265-268$ \\
K2 & $45-72$ & $035-071$ \\
K3 & $78-86$ & $328-343$ \\
K4 & $52-75$ & $139-151$ \\
K5 & $70-75$ & $010-015$ \\
\hline
\end{tabular}

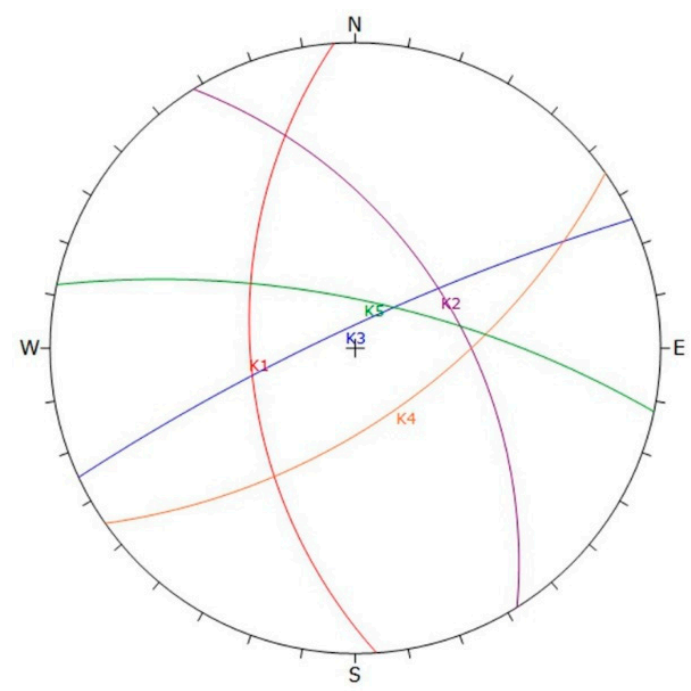

Figure 11. Main discontinuity sets obtained from in situ survey (orientation in Table 2). 


\subsection{Traces Identification}

The process of identification of discontinuity traces by means of the Trace tool, included in qCompass plugin of CloudCompare [60], was performed on point clouds representing excavation faces 1 and 3. Traces were outlined manually drawing segments that followed trace paths: the result associated to each segment is its orientation expressed in terms of trend/plunge. By representing the orientation data on stereonets and performing a cluster analysis, the authors were able to identify sets $\mathrm{K} 3$ and $\mathrm{K} 4$ in the portion of the point cloud representing excavation face 1 and $\mathrm{K} 2-\mathrm{K} 3-\mathrm{K} 4$ sets in the one representing excavation face 3 (Figure 12).
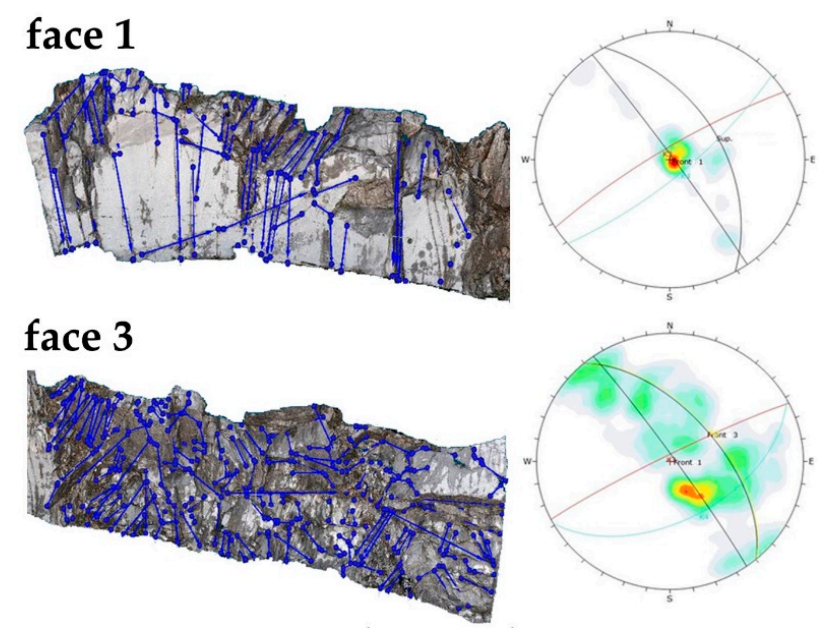

Figure 12. Traces identification (blue lines) on the portions of point cloud of the studied bench representing excavation faces 1 and 3 and obtained stereonets.

Regarding the model of the entire quarry, having a lower resolution, only the most significant discontinuities along three excavation faces named A, B, and C were considered (Figure 13). Sets K1 and $\mathrm{K} 4$ were found in face $\mathrm{A}$, while in the other faces, sets $\mathrm{K} 3, \mathrm{~K} 4$, and $\mathrm{K} 5$ were identified.
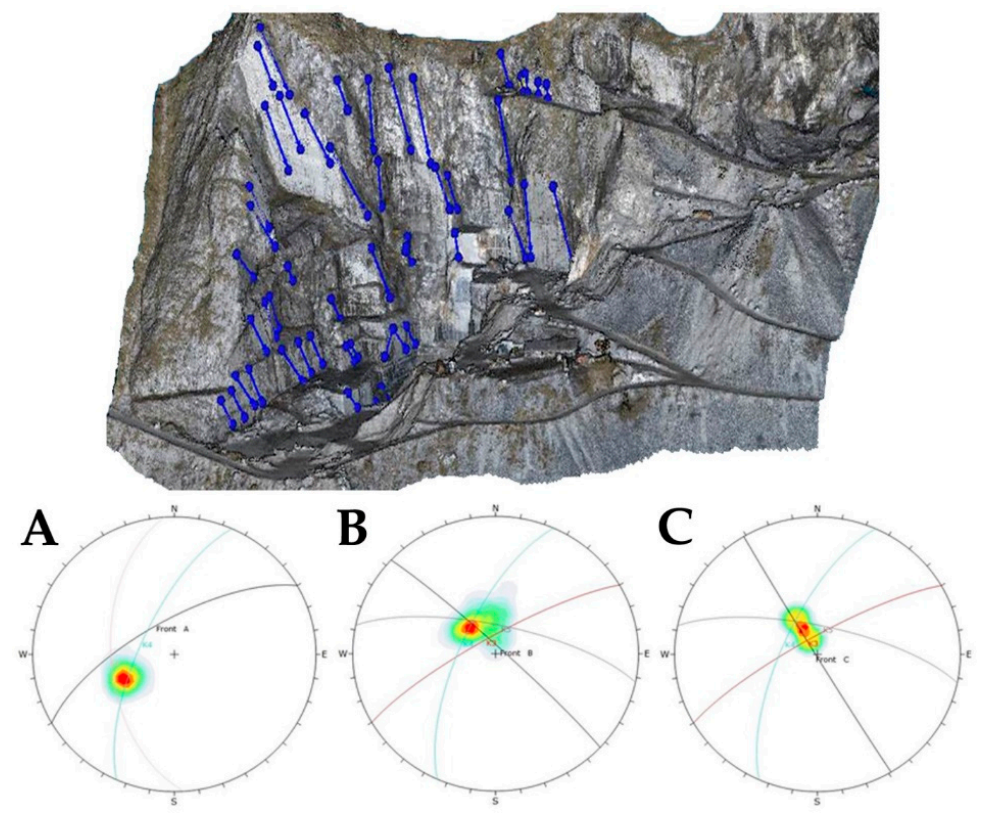

Figure 13. Traces identification (blue lines) on the portion of point cloud of the entire quarry representing excavation faces A, B and C and obtained stereonets. 


\subsection{Stability Analysis}

The results of the kinematic analyses performed following the modified Markland test are reported in Tables 3 and 4. This kind of analysis only indicates the susceptibility of a front with respect to a certain failure mechanism, because the test is based only on geometrical and frictional conditions. Therefore, no indications regarding the probability of occurrence, when or where it can occur are given. However, in a peculiar environment such as a marble quarry, in which there is a continuous change of the morphology, this kind of stability assessment is fundamental in order to understand which directions of excavation could involve instabilities.

Table 3. Summary of potential failure mechanisms that may affect excavation faces from 1 to 7.

\begin{tabular}{ccc}
\hline Face (Dip/Dip Direction) & Planar Sliding & Wedge Sliding \\
\hline $1(87 / 055)$ & $\mathrm{K} 2$ & $\mathrm{~K} 2-\mathrm{K} 3$ \\
$2(88 / 345)$ & $\mathrm{K} 3$ & $\mathrm{~K} 2-\mathrm{K} 4$ \\
$3(60 / 050)$ & $\mathrm{K} 2$ & $\mathrm{~K} 2-\mathrm{K} 3$ \\
& & $\mathrm{~K} 2-\mathrm{K} 3$ \\
$4(89 / 353)$ & $\mathrm{K} 5$ & $\mathrm{~K} 1-\mathrm{K} 5$ \\
$5(89 / 057)$ & - & $\mathrm{K} 1-\mathrm{K} 2$ \\
$6(89 / 300)$ & - & - \\
$7(89 / 048)$ & - & $\mathrm{K} 1-\mathrm{K} 5$ \\
\hline
\end{tabular}

Table 4. Summary of potential failure mechanisms that may affect excavation faces A, B, and C.

\begin{tabular}{ccc}
\hline Face (Dip/Dip Direction) & Planar Sliding & Wedge Sliding \\
\hline & & $\mathrm{K} 1-\mathrm{K} 5$ \\
$\mathrm{~A}(70 / 330)$ & - & $\mathrm{K} 2-\mathrm{K} 4$ \\
& & $\mathrm{~K} 4-\mathrm{K} 5$ \\
\hline & & $\mathrm{K} 2-\mathrm{K} 3$ \\
$\mathrm{~B}(86 / 043)$ & $\mathrm{K} 2$ & $\mathrm{~K} 2-\mathrm{K} 4$ \\
& & $\mathrm{~K} 2-\mathrm{K} 5$ \\
& & $\mathrm{~K} 3-\mathrm{K} 5$ \\
& & $\mathrm{~K} 4-\mathrm{K} 5$ \\
$\mathrm{C}(89 / 239)$ & - & $\mathrm{K} 1-\mathrm{K} 2$ \\
\hline & & $\mathrm{K} 1-\mathrm{K} 3$ \\
& & $\mathrm{~K} 1-\mathrm{K} 4$ \\
& & $\mathrm{~K} 1-\mathrm{K} 5$ \\
& & $\mathrm{~K} 3-\mathrm{K} 4$ \\
\hline
\end{tabular}

Excavation faces resulted susceptible to planar sliding, mainly along discontinuities belonging to set K2, and to wedge sliding: different combinations among discontinuity sets were found to be able to potentially isolate wedges, depending on front orientation.

Thanks to traditional survey performed by the authors it was possible to obtain geotechnical parameters useful for calculating FoS, such as JRC (with a profile gauge or Barton's comb) and JCS (with Schmidt hammer) (Table 5). In addition, persistence P was assumed equal to the ratio between the longest trace length of the considered discontinuity set measurable on an excavation face and the dimension of the face that is more similar to the direction of the set. Figure 14 shows an example with a face $5.35 \mathrm{~m}$ high and a sub-vertical trace $5 \mathrm{~m}$ long, resulting in an estimated persistence of 0.935. Residual friction angle $\Phi$ r of discontinuities was obtained from direct shear tests. Unit volume weight, friction angle and cohesion of the rock matrix have been assumed equal to $2700 \mathrm{~kg} / \mathrm{m}^{3}, 36^{\circ}$ and 17.74 $\mathrm{MPa}$, respectively, according to laboratory tests performed by the authors. 
Table 5. Geotechnical parameters used for calculating FoS.

\begin{tabular}{|c|c|c|c|c|}
\hline \multirow[b]{2}{*}{ Face } & \multicolumn{4}{|c|}{ Discontinuities } \\
\hline & $\mathbf{P}[-]$ & $\mathrm{F}_{\mathrm{r}}\left[^{\circ}\right]$ & JRC [-] & $\mathrm{JCS}\left[\mathrm{t} / \mathrm{m}^{2}\right]$ \\
\hline 1 & 0.935 & 28 & 12 & 6220 \\
\hline 2 & 0.930 & 28 & 11 & 9565 \\
\hline 3 & 0.949 & 28 & 8 & 8668 \\
\hline 4 & 0.452 & 28 & 12 & 6118 \\
\hline 6 & 0.922 & 28 & 11 & 6328 \\
\hline A & 0.990 & 28 & 10 & 8668 \\
\hline B & 0.990 & 28 & 10 & 8668 \\
\hline $\mathrm{C}$ & 0.990 & 28 & 10 & 8668 \\
\hline
\end{tabular}

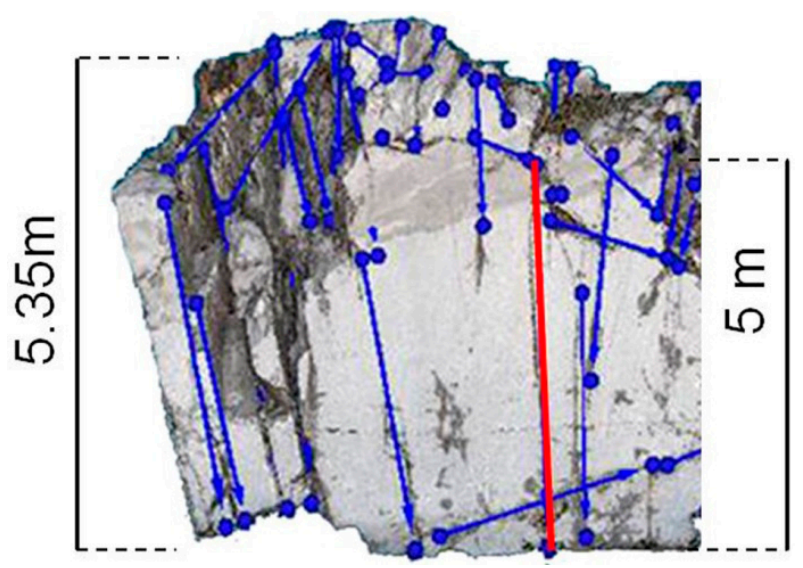

Figure 14. Example of persistence calculation.

Table 6 summarizes the results relating to FoS with respect to planar sliding. As noted, with the Mohr-Coulomb criterion, the absence of cohesion determines conditions of instability, while the presence of rock bridges establishes values markedly higher than the stability threshold (equal to 1).

Table 6. Summary of results in terms of FoS with respect to planar sliding mechanism.

\begin{tabular}{ccccccc}
\hline \multirow{2}{*}{ Face } & \multicolumn{3}{c}{ FoS (Mohr-Coulomb) } & \multicolumn{2}{c}{ FoS (Barton-Bandis) } \\
\cline { 2 - 6 } & $\begin{array}{c}\text { Equation (2) } \\
\text { Spreadsheet }\end{array}$ & $\begin{array}{c}\left.\mathbf{c}_{\text {app }}=\mathbf{0}\right) \\
\text { RocPlane }\end{array}$ & $\begin{array}{c}\text { Equation (3) } \\
\text { Spreadsheet }\end{array}$ & $\begin{array}{c}\text { Equation (4) } \\
\text { RocPlane }\end{array}$ & $\begin{array}{c}\text { Equreadsheet } \\
\text { RocPlane }\end{array}$ \\
\hline 1 & 0.27 & 0.27 & 45.42 & 45.42 & 1.57 & 1.39 \\
2 & 0.10 & 0.10 & 86.60 & 86.60 & 0.94 & 0.53 \\
3 & 0.33 & 0.33 & 381.52 & 381.51 & 1.41 & 1.41 \\
4 & 0.14 & 0.14 & 150.13 & 150.13 & 1.20 & 0.74 \\
B & 0.42 & 0.42 & 3.02 & 3.02 & 1.04 & 1.04 \\
\hline
\end{tabular}

With the Barton-Bandis method, an intermediate situation is outlined with respect to the two ones previously described. The values obtained with the two methods are in accordance.

In the case of wedge sliding, the absence of cohesion determines conditions of instability in most cases (Tables 7 and 8), while rock bridges act to increase the degree of safety significantly: even a small decrease of persistence is able to produce resisting forces more than 10 times greater than acting forces. The values obtained with the two calculation methods are close in most of the cases. Differences between results that should be theoretically equal can be attributed to numerical approximation, particularly influent considering the great number of terms expressed with trigonometric functions that are involved in FoS calculation (see Equations (5) and (6)); in cases in which differences are significant, it is possible to suppose the presence of optimization routines in Swedge code that put geometrical constraints. 
Table 7. Summary of results in terms of FoS with respect to wedge sliding mechanism for excavation faces from 1 to 7 .

\begin{tabular}{|c|c|c|c|c|c|}
\hline \multirow[t]{2}{*}{ Face } & \multirow[t]{2}{*}{ Pair of Sets } & \multicolumn{2}{|c|}{$\begin{array}{c}\text { FoS } \\
\text { Equation }(5)\left(c_{a p p}=0\right)\end{array}$} & \multicolumn{2}{|c|}{$\begin{array}{c}\text { FoS } \\
\text { Equation }(6)\left(c_{\text {app }} \neq 0\right)\end{array}$} \\
\hline & & Spreadsheet & Swedge & Spreadsheet & Swedge \\
\hline \multirow{2}{*}{1} & $\mathrm{~K} 2-\mathrm{K} 3$ & 0.30 & 0.27 & 79.15 & 72.17 \\
\hline & K2-K4 & 0.50 & 0.27 & 89.88 & 81.94 \\
\hline 2 & K2-K3 & 0.38 & 0.10 & 161.07 & 149.37 \\
\hline \multirow{2}{*}{3} & $\mathrm{~K} 2-\mathrm{K} 3$ & 0.31 & 0.37 & 228.14 & 556.37 \\
\hline & $\mathrm{K} 2-\mathrm{K} 4$ & 0.77 & 0.76 & 474.15 & 695.77 \\
\hline \multirow{2}{*}{4} & K1-K5 & 0.77 & 0.80 & 92.23 & 145.81 \\
\hline & $\mathrm{K} 1-\mathrm{K} 2$ & 1.45 & 1.42 & 21.19 & 18.77 \\
\hline 6 & K1-K5 & 0.54 & 0.59 & 8.28 & 6.49 \\
\hline
\end{tabular}

Table 8. Summary of results in terms of FoS with respect to wedge sliding mechanism for excavation faces $\mathrm{A}, \mathrm{B}$, and $\mathrm{C}$.

\begin{tabular}{|c|c|c|c|c|c|}
\hline \multirow[t]{2}{*}{ Face } & \multirow[t]{2}{*}{ Pair of Sets } & \multicolumn{2}{|c|}{$\begin{array}{c}\text { FoS } \\
\text { Equation }(5)\left(c_{a p p}=0\right)\end{array}$} & \multicolumn{2}{|c|}{$\begin{array}{c}\text { FoS } \\
\text { Equation }(6)\left(c_{\text {app }} \neq 0\right)\end{array}$} \\
\hline & & Spreadsheet & Swedge & Spreadsheet & Swedge \\
\hline \multirow{3}{*}{ A } & K1-K5 & 0.63 & 0.67 & 20.55 & 18.99 \\
\hline & $\mathrm{K} 2-\mathrm{K} 4$ & 0.67 & 1.07 & 23.00 & 22.19 \\
\hline & K4-K5 & 0.28 & 0.29 & 88.19 & 73.40 \\
\hline \multirow{6}{*}{ B } & $\mathrm{K} 2-\mathrm{K} 3$ & 0.49 & 0.49 & 12.47 & 11.19 \\
\hline & $\mathrm{K} 2-\mathrm{K} 4$ & 0.67 & 1.07 & 15.02 & 13.69 \\
\hline & K2-K5 & 0.37 & 0.42 & 12.61 & 8.18 \\
\hline & K3-K5 & 0.15 & 0.27 & 40.59 & 39.65 \\
\hline & K4-K5 & 0.28 & 0.16 & 120.10 & 118.65 \\
\hline & $\mathrm{K} 1-\mathrm{K} 2$ & 1.91 & 2.86 & 33.74 & 25.29 \\
\hline \multirow{4}{*}{$\mathrm{C}$} & $\mathrm{K} 1-\mathrm{K} 3$ & 0.36 & 0.52 & 20.01 & 23.70 \\
\hline & $\mathrm{K} 1-\mathrm{K} 4$ & 0.38 & 1.48 & 27.83 & 34.88 \\
\hline & $\mathrm{K} 1-\mathrm{K} 5$ & 0.62 & 0.40 & 29.27 & 20.91 \\
\hline & K3-K4 & 0.16 & 0.51 & 66.16 & 66.89 \\
\hline
\end{tabular}

In general, since no sliding events were reported in the quarry, it is possible to affirm that the more realistic situation to be considered is the one in which cohesion is not null and discontinuities are not fully persistent: basically, rock bridges control the stability. In the peculiar environment of a quarry, this fact highlights the importance of a properly designed exploitation, in order to ensure a safety workplace and not to produce rock bridges sudden breakage.

\subsection{Seismic Conditions}

Finally, the seismic conditions of the study area, which falls into the Zone 2 of the Italian seismic hazard zonation [68], were analyzed with the pseudo static method. This technique considers dynamic forces as static ones by means of a coefficient $k$, proportional to the peak ground acceleration (PGA). Coefficient $\mathrm{k}$ was calculated according to the Italian technical legislation [69], assuming a PGA equal to $0.215 \mathrm{~g}$ (correspondent to a return period of 975 years), a subsoil category A (lithoid material) and a topography category T2 (slope with average inclination higher than $15^{\circ}$ ). In this case, only the horizontal component of the coefficient $\left(\mathrm{k}_{\mathrm{h}}\right)$, equal to 0.077 , was considered.

Tables 9-11 report FoS values obtained considering the presence of seismic action with respect to planar and wedge sliding mechanism; calculation was performed with software RocPlane and SWedge, respectively. 
Table 9. FoS values obtained considering the presence of seismic action with respect to planar sliding mechanism.

\begin{tabular}{cccc}
\hline \multirow{2}{*}{ Face } & \multicolumn{2}{c}{ FoS (Mohr-Coulomb) } & FoS (Barton-Bandis) \\
\cline { 2 - 4 } & $\left(\mathbf{c}_{\text {app }}=\mathbf{0}\right)$ & $\left.\mathbf{( c}_{\text {app }} \neq \mathbf{0}\right)$ & \\
\hline 1 & 0.22 & 43.67 & 1.14 \\
2 & 0.06 & 85.28 & 0.32 \\
3 & 0.28 & 363.96 & 1.20 \\
4 & 0.10 & 147.06 & 0.51 \\
B & 0.35 & 2.81 & 0.90 \\
\hline
\end{tabular}

Table 10. FoS values obtained considering the presence of seismic action with respect to wedge sliding for excavation faces from 1 to 7.

\begin{tabular}{cccc}
\hline \multirow{2}{*}{ Face } & Pair of Sets & FoS & FoS \\
\cline { 3 - 4 } & & $\mathbf{( c}_{\text {app }}=\mathbf{0 )}$ & $\left.\mathbf{( c}_{\text {app }} \neq \mathbf{0}\right)$ \\
\hline \multirow{2}{*}{1} & K2-K3 & 0.22 & 69.43 \\
& K2-K4 & 0.24 & 79.79 \\
\hline \multirow{2}{*}{2} & K2-K3 & 0.09 & 148.31 \\
\multirow{2}{*}{3} & K2-K3 & 0.31 & 509.98 \\
& K2-K4 & 0.65 & 624.73 \\
\hline \multirow{2}{*}{4} & K1-K5 & 0.69 & 134.15 \\
& K1-K2 & 1.18 & 16.25 \\
\hline \multirow{2}{*}{6} & K1-K5 & 0.50 & 6.06 \\
\hline
\end{tabular}

Table 11. FoS values obtained considering the presence of seismic action with respect to wedge sliding for excavation faces $\mathrm{A}, \mathrm{B}$, and $\mathrm{C}$.

\begin{tabular}{cccc}
\hline \multirow{2}{*}{ Face } & Pair of Sets & FoS & FoS \\
\cline { 3 - 4 } & & $\mathbf{( c}_{\text {app }}=\mathbf{0 )}$ & $\left.\mathbf{( c}_{\text {app }} \neq \mathbf{0}\right)$ \\
\hline \multirow{3}{*}{$\mathrm{A}$} & K1-K5 & 0.57 & 17.68 \\
& K2-K4 & 0.91 & 20.13 \\
& K4-K5 & 0.23 & 70.98 \\
\hline \multirow{2}{*}{ B } & K2-K3 & 0.41 & 10.50 \\
& K2-K4 & 0.91 & 12.40 \\
& K2-K5 & 0.36 & 7.71 \\
& K3-K5 & 0.20 & 38.65 \\
& K4-K5 & 0.13 & 116.50 \\
K1-K2 & 2.21 & 19.98 \\
\hline \multirow{2}{*}{ C } & K1-K3 & 0.44 & 22.32 \\
& K1-K4 & 1.27 & 32.30 \\
& K1-K5 & 0.35 & 19.90 \\
& K3-K4 & 0.40 & 64.73 \\
\hline
\end{tabular}

Similar to results in Table 6, with Mohr-Coulomb criterion the absence of cohesion determines conditions of instability (Table 9), while the presence of rock bridges establishes values markedly higher than the stability threshold (equal to 1). With Barton-Bandis method an intermediate situation is outlined with respect to the two ones previously described.

Moreover, similar to results in Tables 7 and 8, in the case of wedge sliding, the absence of cohesion determines conditions of instability in almost every case (Tables 10 and 11).

In general, it is possible to observe a slight decrease of all the calculated FoS values, due to the presence of the seismic action. 


\section{Conclusions}

In ornamental stone quarries, the application of non-contact survey techniques for rock mass characterization is a relatively recent research topic. This study aimed to highlight the potential of the application of non-contact survey based on point clouds to the stability assessment of a marble quarry. To guarantee the completeness of the discontinuity database, this survey was performed in conjunction with traditional survey methodologies. The results obtained confirm the potential of non-contact survey techniques for the geomechanical study of a quarry, in particular in terms of data sample reliability. Non-contact techniques, besides guaranteeing a higher safety level of the operators and the observation of inaccessible parts, allow for the analysis of all the discontinuities on the entire surface of the rock face.

The results of application of CloudCompare for the identification of discontinuity traces demonstrate the great potential of this code on perfectly flat excavation faces: discontinuity sets were recognized by performing a cluster analysis on traces orientation. In view of the excavation progress, this could represent an efficient alternative to a standard survey of discontinuity planes, which would not produce results on excavation faces.

Markland testing of the obtained discontinuity sets revealed the susceptibility of many rock faces to two potential failure modes (planar and wedge sliding), which were further analyzed with LEM methods. Since no failures have been reported during the excavation activity, stability analyses were focused on the evaluation of the influence of discontinuity strength. The authors considered the presence of rock bridges, as these represent a source of cohesion and contribute to an increase in the resisting force opposing the sliding. Results in terms of FoS, assuming the Mohr-Coulomb criterion, demonstrate that the absence of cohesion determines conditions of instability, while the presence of rock bridges results in values markedly higher than the stability threshold (equal to 1 ). The Barton-Bandis method, assumed for planar sliding, produces an intermediate situation with respect to the two previously described. This comparison shows that even a small percentage of rock bridges contribute to stability more than peak resistance conditions. Rock bridges, whose quantification is actually very difficult in terms of geometry and strength, basically control the stability of the slopes in the quarry, therefore they should be the subject of a detailed investigation, involving geometrical and mineralogical aspects.

The seismic conditions of the quarry were also considered: the observed slight decrease of FoS values produced by the seismic action does not affect the rock mass stability in cases in which the presence of rock bridges is considered; in the other cases the already observed instability conditions worsen in terms of calculated FoS.

Author Contributions: Conceptualization, A.M.F. and R.C.; methodology, S.B. (Sabrina Bonetto); software, G.U.; validation, G.U. and S.B. (Sabrina Bonetto); formal analysis, G.U., A.M.F., and A.B.; investigation, A.B.; resources, S.B. (Stefano Bianchini); data curation, A.B.; writing—original draft preparation, A.B., A.M.F., and M.S.; writing-review and editing, G.U.; visualization, A.B.; supervision, A.M.F. and R.C.; project administration, A.M.F., M.R.M., and R.C.; funding acquisition, S.B. (Stefano Bianchini). All authors have read and agreed to the published version of the manuscript.

Funding: This research received no external funding.

Acknowledgments: Authors would like to thank Paolo Corradeghini, who performed the photogrammetric surveys and provided the point clouds used in this study.

Conflicts of Interest: The authors declare no conflict of interest.

\section{References}

1. Priest, S.D. The collection and analysis of discontinuity orientation data for engineering design, with examples. In Rock Testing and Site Characterization; Hudson, J.A., Ed.; Pergamon: Oxford, UK, 1993; pp. 167-192.

2. International Society for Rock Mechanics. ISRM commission on standardization of laboratory and field tests: Suggested methods for the quantitative description of discontinuities in rock masses. Int. J. Rock Mech. Min. 1978, 15, 319-368. [CrossRef] 
3. Davis, J.C. Statistics and Data Analysis in Geology; Wiley: New York, NY, USA, 1986.

4. Kulatilake, P.H.S.W.; Wathugala, D.N.; Stephansson, O. Joint network modelling with a validation exercise in Stripa mine, Sweden. Int. J. Rock Mech. Min. 1993, 30, 503-526. [CrossRef]

5. Crosta, G. Evaluating rock mass geometry from photographic images. Rock Mech. Rock Eng. 1997, 30, 35-58. [CrossRef]

6. Reid, T.R.; Harrison, J.P. A semi-automated methodology for discontinuity trace detection in digital images of rock mass exposures. Int. J. Rock Mech. Min. 2000, 37, 1073-1089. [CrossRef]

7. Post, R.; Kemeny, J.; Murphy, R. Image Processing for Automatic Extraction of Rockjoint Orientation Data from Digital Images. In Proceedings of the 38th US Rock Mechanics Symposium, Washington, DC, USA, 7-10 July 2001; pp. 877-884.

8. Kemeny, J.; Post, R. Estimating three-dimensional rock discontinuity orientation from digital images of fracture traces. Comput. Geosci. 2003, 29, 65-77. [CrossRef]

9. Lemy, F.; Hadjigeorgiou, J. Discontinuity trace map construction using photographs of rock exposures. Int. J. Rock Mech. Min. 2003, 40, 903-917. [CrossRef]

10. Deb, D.; Hariharan, S.; Rao, U.M.; Chang-Ha, R. Automatic detection and analysis of discontinuity geometry of rock mass from digital images. Comput. Geosci. 2008, 34, 115-126. [CrossRef]

11. Mohebbi, M.; Yarahmadi Bafghi, A.R.; Fatehi Marji, M.; Gholamnejad, J. Rock mass structural data analysis using image processing techniques (Case study: Choghart iron ore mine northern slopes). J. Min. Environ. 2017, 8, 61-74. [CrossRef]

12. Underground Application of Photographic and GPR Techniques for Discontinuity Survey. Available online: http://www.patroneditore.com/Rig/2019/2/7892/applicazione_in_sotterraneo_di_tecniche_ fotografiche_e_gpr_per_il_rilievo_di_discontinuit.html (accessed on 7 February 2020).

13. Nguyen, T.L.; Hall, S.A.; Vacher, P.; Viggiani, G. Fracture mechanisms in soft rock: Identification and quantification of evolving displacement discontinuities by extended digital image correlation. Tectonophysics 2011, 503, 117-128. [CrossRef]

14. Blaber, J.; Adair, B.; Antoniou, A. Ncorr: Open-Source 2D Digital Image Correlation Matlab Software. Exp. Mech. 2015, 55, 1105-1122. [CrossRef]

15. Caselle, C.; Umili, G.; Bonetto, S.; Ferrero, A.M. Application of DIC analysis method to the study of failure initiation in gypsum rocks. Geotech. Lett. 2019, 9, 35-45. [CrossRef]

16. Kemeny, J.; Donovan, J. Rock mass characterization using LiDAR and automated point cloud processing. Ground Eng. 2005, 38, 26-29.

17. Trinks, I.; Clegg, P.; McCaffrey, K.; Jones, R.; Hobbs, R.; Holdsworth, B. Mapping and analyzing virtual outcrops. Vis. Geosci. 2005, 10, 13-19. [CrossRef]

18. Feng, Q.; Roshoff, K. A Survey of 3D Laser Scanning Techniques for Application to Rock Mechanics and Rock Engineering. In The ISRM Suggested Methods for Rock Characterization, Testing and Monitoring 2007-2014; Ulusay, R., Ed.; Springer: Berlin/Heidelberg, Germany, 2014; pp. 265-293.

19. Haneberg, W.C. 3-D rock mass characterization using terrestrial digital photogrammetry. AEG News 2006, 49, 12-15.

20. Ferrero, A.M.; Forlani, G.; Roncella, R.; Voyat, H.I. Advanced Geostructural survey Methods Applied to Rock Mass Characterization. Rock Mech. Rock Eng. 2009, 42, 631-665. [CrossRef]

21. Sturzenegger, M.; Stead, D. Close-range terrestrial digital photogrammetry and terrestrial laser scanning for discontinuity characterization on rock cuts. Eng. Geol. 2009, 106, 163-182. [CrossRef]

22. Gigli, G.; Casagli, N. Semi-automatic extraction of rock mass structural data from high resolution LIDAR point clouds. Int. J. Rock Mech. Min. 2011, 48, 187-198. [CrossRef]

23. Lato, M.; Vöge, M. Automated mapping of rock discontinuities in 3D LIDAR models. Int. J. Rock Mech. Min. 2012, 54, 150-158. [CrossRef]

24. Riquelme, A.J.; Abellán, A.; Tomás, R.; Jaboyedoff, M. A new approach for semi-automatic rock mass joints recognition from 3D point clouds. Comput. Geosci. 2014, 68, 38-52. [CrossRef]

25. Francioni, M.; Salvini, R.; Stead, D.; Giovannini, R.; Riccucci, S.; Vanneschi, C.; Gullì, D. An integrated remote sensing-GIS approach for the analysis of an open pit in the Carrara marble district, Italy: Slope stability assessment through kinematic and numerical methods. Comput. Geotech. 2015, 67, 46-63. [CrossRef] 
26. Matasci, B.; Carrea, D.; Abellan, A.; Derron, M.H.; Humair, F.; Jaboyedoff, M.; Metzger, R. Geological mapping and fold modeling using Terrestrial Laser Scanning point clouds: Application to the Dents-du-Midi limestone massif (Switzerland). Eur. J. Remote Sens. 2015, 48, 569-591. [CrossRef]

27. Masoud, A.; Koike, K. Autodetection and integration of tectonically significant lineaments from SRTM DEM and remotely-sensed geophysical data. ISPRS J. Photogramm. Remote Sens. 2011, 66, 818-832. [CrossRef]

28. Bonetto, S.; Facello, A.; Ferrero, A.M.; Umili, G. A Tool for Semi-Automatic Linear Feature Detection Based on DTM. Comput. Geosci. 2015, 75, 1-12. [CrossRef]

29. Bonetto, S.; Facello, A.; Umili, G. A new application of CurvaTool semi-automatic approach to qualitatively detect geological lineaments. Environ. Eng. Geosci. 2017, 23, 179-190. [CrossRef]

30. Bonetto, S.; Facello, A.; Umili, G. The contribution of CurvaTool semi-automatic approach in structural and groundwater investigations. A case study in the Main Ethiopian Rift Valley. Egypt. J. Remote Sens. Space Sci. 2018. [CrossRef]

31. Kim, D.H.; Gratchev, I.; Balasubramaniam, A. Back analysis of a natural jointed rock slope based on the photogrammetry method. Landslides 2015, 12, 147-154. [CrossRef]

32. Assali, P.; Grussenmeyer, P.; Villemin, T.; Pollet, N.; Viguier, F. Surveying and modeling of rock discontinuities by terrestrial laser scanning and photogrammetry: Semi-automatic approaches for linear outcrop inspection. J. Struct Geol. 2014, 66, 102-114. [CrossRef]

33. Racaniello, A.; Bonetto, S.; Enrici Baion, R.; Ferrero, A.M.; Umili, G. Caratterizzazione di ammassi rocciosi in sotterraneo mediante rilievo geostrutturale "non a contatto". GEAM 2015, 2, 51-58.

34. Coïsson, E.; Segalini, A.; Bonetto, S. Buildings under the Rocks: An Interdisciplinary Approach for a Safe Conservation. Procedia Eng. 2016, 161, 2222-2228. [CrossRef]

35. Umili, G.; Bonetto, S.; Ferrero, A.M. An integrated multiscale approach for characterization of rock masses subjected to tunnel excavation. J. Rock Mech. Geotech. Eng. 2018, 10, 513-522. [CrossRef]

36. Ferrero, A.M.; Migliazza, M.; Pirulli, M.; Umili, G. Some Open Issues on Rockfall Hazard Analysis in Fractured Rock Mass: Problems and Prospects. Rock Mech. Rock Eng. 2016, 49, 3615-3629. [CrossRef]

37. Curtaz, M.; Ferrero, A.M.; Roncella, R.; Segalini, A.; Umili, G. Terrestrial photogrammetry and numerical modelling for the stability analysis of rock slopes in high mountain areas: Aiguilles Marbrées case. Rock Mech. Rock Eng. 2014, 47, 605-620. [CrossRef]

38. Agliardi, F.; Crosta, G.B.; Meloni, F.; Valle, C.; Rivolta, C. Structurally-controlled instability, damage and slope failure in a porphyry rock mass. Tectonophysics 2013, 605, 34-47. [CrossRef]

39. Havaej, M.; Coggan, J.; Stead, D.; Elmo, D. A combined remote sensing-numerical modelling approach to the stability analysis of Delabole Slate Quarry, Cornwall, UK. Rock Mech. Rock Eng. 2016, 49, 1227-1245. [CrossRef]

40. Rafeh, F.; Mroueh, H.; Burlon, S. Accounting for joints effect on the failure mechanisms of shallow underground chalk quarries. Comput. Geotech. 2015, 69, 247-261. [CrossRef]

41. Alejano, L.R.; Veiga, M.; Pérez-Rey, I.; Castro-Filgueira, U.; Arzúa, J.; Castro-Caicedo, Á.J. Analysis of a complex slope failure in a granodiorite quarry bench. Bull. Eng. Geol. Environ. 2019, 78, 1209-1224. [CrossRef]

42. Shang, J.; West, L.J.; Hencher, S.R.; Zhao, Z. Geological discontinuity persistence: Implications and quantification. Eng. Geol. 2018, 241, 41-54. [CrossRef]

43. Hencher, S.R.; Richards, L.R. Assessing the Shear Strength of Rock Discontinuities at Laboratory and Field Scales. Rock Mech. Rock Eng. 2015, 48, 883-905. [CrossRef]

44. Alejano, L.R.; Castro-Filgueira, U.; Pérez-Rey, I.; Arzúa, J. Stability Analysis of an Over-tilted Slope in a Granite Quarry: The Role of Joint Spacing. Procedia Eng. 2017, 191, 402-409. [CrossRef]

45. Giani, G.P. Rock Slope Stability Analysis; Balkema: Rotterdam, The Netherlands, 1992.

46. Richards, L.R.; Leg, G.M.M.; Whittle, R.A. Appraisal of stability conditions in rock slopes. In Foundation Engineering in Difficult Ground; Newnes-Butterworths: London, UK, 1978; pp. 449-512.

47. Hoek, E.; Bray, J.W. Rock Slope Engineering, 3rd ed.; The Institution of Mining and Metallurgy: London, UK, $1981 ; 358$ p.

48. Carmignani, L.; Kligfield, R. Crustal extension in the Northern Apennines: The transition from compression to extension in the Alpi Apuane core complex. Tectonics 1990, 9, 1275-1303. [CrossRef]

49. Molli, G.; Giorgetti, G.; Meccheri, M. Tectono-metamorphic evolution of the Alpi Apuane metamorphic complex: New data and constraints for geodynamic models. Boll Soc. Geol. Ital. 2002, 1, 789-800. 
50. Molli, G. Northern Apennine-Corsica orogenic system: An updated review. In Tectonic Aspects of the Alpine-Dinaride-Carpathian System: 2008; Siegesmund, S., Fügenschuh, B., Froitzheim, N., Eds.; Geological Society of London: London, UK, 2008. [CrossRef]

51. Kligfield, R.; Hunziker, J.; Dallmeyer, R.D.; Schamel, S. Dating of deformational phases using K-Ar and 40Ar/39Ar techniques: Results from the Northern Apennines. J. Struct. Geol. 1986, 8, 781-798. [CrossRef]

52. Molli, G. Deformation and fluid flow during underplating and exhumation of the Adria continental margin: A one day field trip in the Alpi Apuane (northern Apennines, Italy). In Deformation, Fluid Flow and Mass Transfer in the Forearc of Convergent Margins: Field Guides to the Northern Apennines in Emilia and the Apuan Alps (Italy): 2012; Vannucchi, P., Fisher, D., Eds.; The Geological Society of America: New York, NY, USA, 2012. [CrossRef]

53. Fellin, M.G.; Reiners, P.W.; Brandon, M.T.; Wuthrich, E.; Balestrieri, M.L.; Molli, G. Thermo-chronologic evidence of exhumational history of the Alpi Apuane metamorphic core complex, northern Apennines, Italy. Tectonics 2007, 26. [CrossRef]

54. Conti, P.; Carmignani, L.; Massa, G.; Meccheri, M.; Fantozzi, P.L.; Masetti, G.; Rossetto, R. Note Illustrative Della Carta Geologica d'Italia Alla Scala 1:50,000 "Foglio 260-Viareggio"; Progetto CARG, ISPRA, Istituto Superiore per la Protezione e la ricerca Ambientale, Servizio Geologico d'Italia: Rome, Italy, 2012.

55. Conti, P.; Carmignani, L.; Giglia, G.; Meccheri, M.; Fantozzi, P.L. Evolution of geological interpretations in the Alpi Apuane Metamorphic Complex, and their relevance for the geology of the Northern Apennines. In The Regione Toscana Project of Geological Mapping; Morini, D., Bruni, P., Eds.; Regione Toscana-Servizio Geologico Regionale: Firenze, Italy, 2004; Volume 23, pp. 241-262.

56. Carmignani, L.; Conti, P.; Disperati, L.; Fantozzi, P.L.; Giglia, G.; Meccheri, M. Carta Geologica del Parco delle Alpi Apuane, 1:50,000; Se.l.ca: Firenze, Italy, 2000.

57. Molli, G.; Giorgetti, G.; Meccheri, M. Structural and petrological constraints on the tectono-metamorphic evolution of the Massa Unit (Alpi Apuane, NW Tuscany, Italy). Geol. J. 2000, 35, 251-264. [CrossRef]

58. Lorenzoni, V.; Università di Siena, Arezzo, Italy. Progetto Di Coltivazione Della Cava "Piastrone": Studio Geomeccanico e Analisi di Stabilità. Personal communication, 2012.

59. Agisoft Photoscan. Available online: https://www.agisoft.com/features/ (accessed on 11 October 2019).

60. CloudCompare, 3D Point Cloud and Mesh Processing Software, Open Source Project. Available online: http://www.cloudcompare.org (accessed on 11 October 2019).

61. Markland, J.T. A Useful Technique for Estimating the Stability of Rock Slope When the Rigid Wedge Sliding Type of Failure Is Expected; Imperial College of Science and Technology: Landon, UK, 1972.

62. Hudson, J.A.; Harrison, J.P. Engineering Rock Mechanics-An Introduction to the Principles; Pergamon Press: Oxford, UK, 1997.

63. Rocscience-Dips. Available online: https://www.rocscience.com/software/dips (accessed on 11 October 2019).

64. Barton, N.R.; Bandis, S. Review of predictive capabilities of JRC-JCS model in engineering practice. In Rock Joints, Proceedings of the International Symposium on Rock Joints, Loen, Oslo, Norway, 4-6 June 1990; Barton, N., Stephansson, O., Eds.; Balkema: Rotterdam, The Netherlands, 1990; pp. 603-610.

65. Bonilla-Sierra, V.; Scholtès, L.; Donzé, F.V.; Elmouttie, M. DEM analysis of rock bridges and the contribution to rock slope stability in the case of translational sliding failures. Int. J. Rock Mech. Min. 2015, 80, 67-78. [CrossRef]

66. Rocscience-RocPlane. Available online: https://www.rocscience.com/software/rocplane (accessed on 11 October 2019).

67. Rocscience-SWedge. Available online: https://www.rocscience.com/software/swedge (accessed on 11 October 2019).

68. Ordinanza PCM 3519 Del 28 Aprile 2006, All. 1b: Pericolosità Sismica Di Riferimento Per il Territorio Nazionale. Available online: http://zonesismiche.mi.ingv.it/mappa_ps_apr04/consultazione_005.html (accessed on 11 October 2019).

69. NTC. Norme Tecniche per le Costruzioni, Ministero Delle Infrastrutture e Dei Trasporti, Decreto Ministeriale del 14 Gennaio 2008, Supplemento Ordinario Alla G.U. n. 29 del 4 Febbraio 2008. Available online: https://www.gazzettaufficiale.it/eli/id/2008/02/04/08A00368/sg (accessed on 11 October 2019).

(C) 2020 by the authors. Licensee MDPI, Basel, Switzerland. This article is an open access article distributed under the terms and conditions of the Creative Commons Attribution (CC BY) license (http://creativecommons.org/licenses/by/4.0/). 